\title{
Quantification and utilization of agricultural wastes in farm based rural households of Jorhat district of Assam
}

Bijoylaxmi Bhuyan, Leena Das and Pallavi Talukdar

Received: 29.01.2018; Revised: 06.05.2018; Accepted: 23.05.2018

See end of the paper for authors' affiliations Pallavi Talukdar Department of Family Resource Management and Consumer Studies, College of Community Science, Assam Agricultural University, Jorhat (Assam) India
ABSTRACT : A well structured interview schedule was administered on hundred rural households of eleven villages of Jorhat district of Assam during 2016-17 to conduct a survey specially on accumulation and utilization of agricultural wastes in rural households. Result indicated that majority of the farmers $(30 \%)$ were of middle age group (30-40 years), mostly having a nuclear family $(73 \%)$ with $1-5$ members with an educational qualification upto $10^{\text {th }}$ standard. Majority of the respondents are marginal farmer with a land holding upto 10 acres and earn their livelihood primarily from farming. Most of the households cultivated paddy as monocrop. However, Rabi and Kharif vegetables were also grown by many households depending upon the land situation. Data reveals that 10,396 qt rice straw, 18,193 qt of rice husk, $2004.64 \mathrm{~kg}$ of water hyacinth and 12000 number of areca sheath are produced as agricultural wastes among the 100 households. The study also reveals that there is a huge gap between the availability of agricultural wastes and awareness for economic utilizing these wastes.

KEY WORDS: Agricultural wastes, Water hyacinth, Rice straw, Rice husk

- HOW TO CITE THIS PAPER : Bhuyan, Bijoylaxmi, Das, Leena and Talukdar, Pallavi (2018). Quantification and utilization of agricultural wastes in farm based rural households of Jorhat district of Assam. Asian J. Home Sci., 13 (1) : 400-404, DOI: 10.15740/HAS/AJHS/13.1/400-404. Copyright@ 2018: Hind Agri-Horticultural Society. 